\title{
AS GESTICULAÇÕES DOS ESTUDANTES EM LABORATÓRIO DE QUÍMICA E SUA INTERPRETAÇÃO BASEADA NA SEMIÓTICA PEIRCEANA
}

\author{
Wanda Naves Cocco Salvadego \\ Colégio Estadual Antonio Tortato (EMN) \\ Secretaria de Educação do Paraná \\ Curitiba, Paraná \\ E-mail: wandacocco@yahoo.com.br
}

\section{Carlos Eduardo Laburú}

Universidade Estadual de Londrina

Londrina, Paraná

E-mail: laburu@uel.br

Resumo: Este trabalho é parte de uma tese de doutorado que investiga quais os sentidos que as gesticulações dos estudantes transmitem em relação à aprendizagem dos conceitos envolvidos em atividades experimentais de química e interpreta essas gesticulações por meio de um instrumento semiótico baseado na reinterpretação de uma leitura da Teoria semiótica peirciana. A pesquisa é qualitativa e descritiva, com estudantes do ensino médio Técnico em Química, do segundo e terceiro ciclo do Ensino Subsequente do Noroeste do Estado do Paraná. Do ponto de vista da importância pedagógica, a gesticulação sintetiza duas dimensões a serem atendidas: a cognitiva e a avaliativa processual, de interesse deste trabalho. Os resultados indicam a necessidade de se tornar mais conhecidos instrumentos pedagógicos como o que avaliamos neste trabalho para que o ensino-aprendizagem, no nosso caso especial, em laboratório, possa ser feito de forma mais imediata e efetiva.

Palavras-chave: gesticulação, semiótica, atividades experimentais, ensino de química.

\section{THE GESTICULATION OF STUDENTS IN CHEMISTRY LABORATORY AND ITS INTERPRETATION BASED ON PEIRCE'S SEMIOTICS}

Abstract: This work is part of a doctoral thesis investigating which way the gesture of students pass towards learning the concepts involved in chemistry experimental activities and interprets these gestures through a semiotic instrument based on the reinterpretation of reading of the Peirce's Semiotics Theory. Presents a qualitative and descriptive research carried out with students from a Technical High School Chemistry Course, of the second and third cycle subsequent education of Paraná State Northwest. From the pedagogical importance stand point, gestures synthetizes two dimensions to be met: a cognitive and the process evaluation, which is the focus of this work. Results show the need to make pedagogical tools, such as this evaluated by this thesis, more known so that the teaching-learning process, and, in this case, the one that takes place in the laboratory, can occur in a more immediate and effective way.

Keywords: gestures, semiotics, experimental activities, chemistry teaching.

Recebido em 16/07/2015. Publicado em 30/03/2016. 


\section{INTRODUÇÃO}

O nosso corpo fala e fazemos o corpo falar, ao utilizá-lo como modo de expressão de uma realidade extracorporal, ou seja, falamos por meio do corpo, na medida em que nos servimos de gestos, mímicas e pantomimas corporais para transmitir informações. A pantomima não ocorre como discurso, também não segue restrições formais e não faz parte da convenção de uma língua. E os gestos integrados podem revelar-nos sobre o processamento de informações através de canais diferentes. Assim, pessoas podem se referir a alguma coisa ao apontá-las, podem empregar as mãos de maneira organizada, em ações complexas, para mostrar o que parece ser, para indicar seu tamanho ou sua forma, para sugerir uma forma, objeto ou processo pelo qual uma ideia abstrata é ilustrada, ou podem mostrar, por meio de ações corporais visíveis, que estão fazendo um questionamento, um pedido, propondo uma hipótese, duvidando da palavra de outro, negando alguma coisa ou indicando concordância a respeito disso e muitas outras coisas (KENDON, 2004).

Foi com o surgimento da tecnologia de gravação de áudio, a gravação sincrônica audiovisual e as informações tecnológicas, que novos e fortes modelos gerais surgiram para análise do processo de comunicação, dentre eles o gesto. Essa aparente dicotomia entre analógico e digital, na comunicação humana, compôs o conceito de comunicação não verbal. A tecnologia áudio visual trouxe vantagem para detalhes de movimentos e permitiu perceber como os gestos e a fala estavam relacionados, pelo fato de as duas atividades estarem intimamente conectadas.

Tendo em vista as pesquisas em andamento, e em contraponto a elas, pretendemos com este trabalho avançar na questão dos gestos, estendendo-os à gesticulação no ensino de química. Por gesticulação entendemos "gestos em ação", ou seja, a ocorrência temporal de uma sequência de gestos instantâneos que se encadeiam, formando e completando uma ação sobre o ambiente empírico. Iremos considerar gesticulação como um sinônimo de pantomima, visto que ela faz o menor uso possível de palavras e maior uso de gestos. Este trabalho é parte de uma investigação maior da tese de doutorado que pesquisou quais os sentidos que as gesticulações dos estudantes transmitem em relação à aprendizagem dos conceitos envolvidos em atividades experimentais de química. Nesse contexto, o objetivo central da pesquisa foi o de interpretar as gesticulações dos estudantes no laboratório de química, baseando-nos numa reinterpretação da semiótica de Peirce. Para isso foi necessário descrever o desenvolvimento das atividades experimentais, fazer a 
análise dessas gesticulações, produzidas pelos estudantes durante a aula e, depois disso, interpretar as gesticulações efetuadas no decorrer da atividade.

\section{GESTOS, GESTICULAÇõES E APLICAÇõES NO ENSINO DE QUÍMICA}

O termo comunicações não verbais é aplicado a gestos, posturas, orientações do corpo, singularidades somáticas, naturais ou artificiais, e até a organização de objetos e relações de distâncias entre os indivíduos, graças aos quais uma informação é emitida (CORRAZE, 1982). Segundo Kendon (2004), o estudo dos gestos é muito antigo. A atenção maior a eles deu-se no final do século XVI. No século XVII, cogitou-se a possibilidade de que eles pudessem formar a base da linguagem universal; no século XVIII, buscou-se a explicação para a origem da linguagem, entendendo-se que os gestos poderiam ser o meio a partir do qual ela foi formada. Seu interesse teve um declínio, no final do século XIX, só voltando a ser revisto a partir de meados do século XX.

Nos anos seguintes, que precederam a segunda guerra mundial, filmes e fotografias começaram a ser usados nos trabalhos antropológicos. Estudos em comunicação demonstram que gestos são frequentemente utilizados, momento a momento, todos os dias, como uma forma de expressão alternativa da fala e também como uma conjunção com esta (KENDON, 2004). Os gestos atraíram interesse por três motivos. Primeiro, por parecerem ser a forma universal e natural de expressão. Segundo, por alguma coisa espontânea ser criada por meio de algo individual. E o terceiro e principal motivo do interesse pelos gestos, nos últimos anos do século $X X$, em especial, devido à linguagem de sinais.

Os gestos dão importante informação sobre as pessoas que os realizam, sobre seu engajamento com os outros e sobre a natureza de suas intenções e atitudes. Na pesquisa realizada por Roth e Lawles (2002) fica demonstrado que, longe de ser ociosa, a expressão corporal gestual proporciona profunda função cognitiva na emergência dos conceitos abstratos científicos dos estudantes, pois, como indicam Kastens et al. (2007), o gesto está intimamente conectado com a percepção e com a cognição e, assim, acarreta sutis significados que, de outra forma, seriam conduzidos de maneira inábil ou mesmo seriam impossíveis de virem a ser conduzidos, caso a linguagem fosse unicamente empregada. 
Ainda que gestos e ações possam ter seus sentidos confundidos e que apenas alguns autores tenham o cuidado de separá-los formalmente (RADFORD, 2009; ROTH; LAWLES, 2002), não existindo maior preocupação nos estudos da área, é preciso advertir que, na perspectiva discutida nesta pesquisa, eles encerram uma nítida distinção conceitual e metodológica. Devido ao foco desta investigação se voltar para as atividades empíricas, o que não ocorre com a maioria dos trabalhos nessa linha de investigação, a exceção de Roth (2007) e Roth e Welzel (2001), as ações para nós têm maior importância do que os gestos. Estes últimos, devido a sua instantaneidade, abandonam o modo de representação no tempo, ou seja, em uma só imagem ou ocorrência gestual instantânea é impossível contar uma história, enquanto pela gesticulação de uma imagem em sequência ou animação proporciona-se um meio para que se constituam narrativas com relações temporais e causais (LABURÚ et al, 2011).

Tal qual o gesto, veremos que uma ação ou gesticulação tem por detrás um significado, pois o protagonista da ação, ao realizá-la, tem em mente uma finalidade concebida que o levou a resolver ou a tentar resolver um problema de interesse prático. Por conseguinte, o foco deste estudo ultrapassa o gesto estático, isolado, e se concentra em perscrutar a ação de estudantes sobre objetos, artefatos e instrumentação científica que se concatenam em arranjos experimentais com o objetivo de ensinar química.

O signo é aquilo que dá corpo ao pensamento, às emoções e às reações, podem ser externalizados, ou seja, traduzidos de internos para externos. Com a evolução contínua dos signos surge a necessidade de que possamos dialogar com eles em um nível mais profundo, buscando compreender como os signos agem nos valendo do avanço da tecnologia e da hipermídia. Eles estão sempre representando algo que se busca decifrar. Em uma atividade experimental, as gesticulações dos estudantes (signos), manipulando os materiais de laboratório e reagentes, transmitem uma mensagem a respeito do conteúdo. Os efeitos interpretativos causados por eles dependem diretamente do modo como o signo representa seu objeto. Dessa forma, os efeitos interpretativos que o signo provoca num receptor podem ser analisados semioticamente, deixando transparecer quais os sentidos que as gesticulações dos estudantes transmitem em relação a aprendizagem dos conceitos envolvidos em atividades experimentais de química. 
As gesticulações dos estudantes foram os signos por nós utilizados para observação e análise dessa relação. Na relação emissor e receptor a gesticulação é um signo de natureza determinantemente não intencional. Ela se apresenta, basicamente, como um ato de autorreflexão e de pensamento interior em ação do emissor, sem que os signos expressos por ele sejam direcionados necessariamente para um receptor. As ações corporais transmitem constantemente intenções, interesses, sentimentos e ideias dos sujeitos que interagem. No entanto, há ações mais expressivas que outras, por isso o sentido de intencionalidade marca a diferença em meio a um enorme número de informações simultâneas. As gesticulações dos estudantes no laboratório de química passam a ser intencionais para quem as interpreta. Então, quando nos referirmos às gesticulações dos estudantes estaremos enfatizando os gestos e ações na manipulação dos objetos de laboratório.

O uso das atividades experimentais no ensino das ciências foi considerado como uma ponte entre o empírico e a construção teórica, promovendo uma interatividade e uma interdependência da teoria e do experimento. Portanto, pode-se dizer muito a respeito do que pensam os estudantes, em aulas experimentais, por meio de suas gesticulações. Elas os auxiliam na elaboração de significados, permitindo a expressão de sentidos que podem ser estudados e analisados. A gesticulação materializa os abstratos conceitos científicos em ação, em procedimento concreto. A experimentação, especialmente no ensino de química, é um modo a mais, que permite acompanhar a relação de conceitos entre prática e conteúdo.

Nesse sentido, este trabalho visa utilizar a semiótica, com base numa reinterpretação da teoria de Peirce, para a análise dos dados e assim, interpretar, por meio das gesticulações dos estudantes, a relação entre o experimento (signo) e o conteúdo já visto, determinado aqui como a experiência colateral, entendido como objeto, ou seja, uma relação signo e objeto, em uma atividade de laboratório de química, com as categorias fenomenológicas, fazendo uso da segunda tricotomia de Peirce.

\subsection{A semiótica peirciana}

As diversas facetas que a análise semiótica apresenta podem nos levar a compreender qual é a natureza e quais os poderes de referência dos signos, que informação transmitem, como eles se estruturam em sistemas, como funcionam, como são emitidos, produzidos, utilizados e que tipo 
de efeitos são capazes de provocar no receptor. Ela não é "uma chave que abre para nós milagrosamente as portas de processos de signos cuja teoria e prática desconhecemos" (SANTAELLA, 2005, p.6). Ela funciona como um mapa lógico, que traça a linha dos diferentes aspectos a partir dos quais uma análise deve ser conduzida, mas não nos traz conhecimento específico da história, teoria e prática de um determinado processo de signos. Sem conhecer a história de um sistema de signos e do contexto sociocultural em que ele se situa não se pode detectar as marcas que o contexto deixa na mensagem.

Quase que simultaneamente, em lugares diferentes, a Semiótica teve três origens distintas e temporalmente sincronizadas: nos EUA, na antiga União Soviética e na Europa Ocidental, impulsionadas a partir da Revolução Industrial, cuja difusão de informações e mensagens de toda a ordem, e a consciência das linguagens, surge a necessidade de estudá-las, uma "consciência semiótica" (SANTAELLA, 2007, p.15). Abordamos nesta pesquisa a semiótica peirciana. A autora ressalta que a semiótica peirciana não é uma ciência especializada, cujo objeto de estudo é delimitado. Em razão do caráter extremamente geral e abstrato, as teorias semióticas seriam extraídas de forma empírica e utilizadas em pesquisas aplicadas. Essas teorias constituem-se como membro da tríade das ciências normativas, estética, ética e lógica ou semiótica, que tem a fenomenologia como base fundamental para qualquer ciência. A criação de categorias é trabalho da fenomenologia, que tem por função realizar as análises de todas as experiências possíveis, e, por meio delas, postular as formas ou propriedades universais desses fenômenos (SANTAELLA, 2007).

A semiótica, concebida como uma lógica, em sentido mais amplo, apresenta basicamente três ramos: o da gramática especulativa, a lógica crítica e a metafísica. A gramática especulativa, primeiro ramo, estuda todos os tipos de signos e os tipos de interpretação que eles podem produzir. Este domínio se subdivide em três níveis: a relação do signo com ele mesmo (o seu poder de significar), com seu interpretante (tipos de interpretação que ele tem o potencial de despertar nos seus usuários) e com seu objeto (aquilo que se refere ou representa), este considerado o mais importante deles.

Na lógica crítica de Peirce, todo e qualquer fenômeno pode ser estabelecido em três categorias: primeiridade, como a capacidade de observar; secundidade, como a capacidade de distinguir, 
discriminar as observações; e terceiridade, a capacidade de generalizar as observações em classes. Essas categorias poder ser resumidas em ver, distinguir e generalizar. A lógica crítica tem como base a diversidade sígnica e estuda os tipos de inferências e raciocínios (abdução, dedução e indução). O último ramo, a retórica especulativa ou metodêutica tem por função analisar os métodos originados por cada tipo de raciocínio. Por último, temos a metafísica como a ciência que "comparece como resultante e não antecedente de toda sua filosofia" (SANTAELLA, 2007, p.29) e se ocupa em estudar o mundo real, onde as forças naturais se manifestam e forjam a realidade em nossa volta.

"A semiótica estuda o mundo das representações e da linguagem" (NICOLAU, 2010, p.2). Para Peirce (CP, 1994), a Semiótica é a ciência dos signos e este signo é algo (A) que denota alguma coisa (B) para alguém (C). Peirce parte do axioma de que a cognição, as ideias e inclusive o homem são essencialmente entidades semióticas. Tudo o que refletimos tem um passado, assim, um signo, uma ideia se refere a outras ideias e objetos $\left(C P, 5.253\right.$, p.1003) ${ }^{1}$. Segundo Peirce, não há nenhum elemento, qualquer que seja, da consciência humana que não tenha algo que corresponda à ideia ou signo, pois estes são próprios do homem. Assim, como o fato de que cada pensamento é um signo, e que a vida é uma linha de pensamento, prova que o homem é um signo (CP, 5.314, p.1020). Em sua interpretação, os signos permeiam o mundo ou, talvez, este seja composto exclusivamente de signos.

Nicolau et al.(2010, p.2-3) esclarece essa ideia de Peirce com o seguinte exemplo:

Imagine que você vem por uma estrada e bem adiante algo chama sua atenção. Um borrão vermelho que se movimenta. Algo cuja qualidade inicial é ser vermelho e isso é tudo o que você capta dele em um primeiro momento. Ao se aproximar começa a visualizar que o vermelho se agita como um pano. Essa é a segunda característica que você consegue identificar: a relação do vermelho com um pano em movimento. Por fim, mais próximo do objeto, você desvenda sua dúvida: alguém agita uma bandeira vermelha na beira da estrada compreendida imediatamente como sendo um aviso de que há perigo mais adiante. É desse modo que nos situamos no mundo em nossa volta: primeiro os objetos surgem

\footnotetext{
${ }^{1}$ As citações de Peirce, do Collected Papers, serão identificadas com CP e os números se referem, respectivamente, ao volume e aos parágrafos no texto digital.
} 
em nossa mente como qualidades potenciais; segundo, procuramos uma relação de identificação e terceiro, nossa mente faz a interpretação do que se trata. Por isso a Semiótica se baseia numa tríade de classificações e inferências, ao demonstrar que existem os objetos no mundo.

Para Peirce, é dessa maneira que reconhecemos e interpretamos o mundo à nossa volta. Primeiro, como coisas que se apresentam à nossa mente, sem referência a outra qualquer, como uma mera possibilidade, uma qualidade potencial. Segundo, relacionamos a outra coisa, procurando uma relação de identificação, e terceiro, nossa mente faz a interpretação dessa relação, uma síntese do que se trata. São três as categorias necessárias para organizar o pensamento, segundo Peirce, e se baseiam numa tríade de classificações e inferências para demonstrar que existem os objetos no mundo, suas representações, em forma de signos, e nossa interpretação mental desses objetos.

Signo é algo que denota alguma coisa para alguém, é aquilo que está no lugar de algo. Segundo Peirce (1977, p.46):

Signo ou representamen é tudo aquilo que sob um certo aspecto ou medida, está para alguém em lugar de algo Dirige-se a alguém, isto é, cria, na mente dessa pessoa, um signo equivalente ou talvez um signo mais desenvolvido. Ao signo assim criado denomino interpretante do primeiro signo. O signo representa alguma coisa, seu objeto. Representa esse objeto não em todos os seus aspectos, mas com referência a um tipo de ideia que eu, por vezes, denominei fundamento do representamen.

Essas três entidades: signo, objeto e interpretante, formam a relação triádica de signo. A semiótica busca discernir e deslindar a ação de signo. O signo é a função do objeto, do representamen e do interpretante no processo de semiose, dessa forma tem sua existência na mente do receptor e não no mundo exterior (NÖTH, 1995). Assim, é da natureza de um signo ser interpretado como signo, pois, se assim não for, nada é signo (PEIRCE, 1977). Semiose e Semiótica são coisas distintas. Para Peirce (CP, 5.484), a semiose é a ação do signo, é o "processo no qual o signo tem um efeito cognitivo sobre o intérprete". A semiótica é um enunciado teórico sobre os fenômenos semiósicos, ou seja, a semiose é o objeto de estudo da semiótica (NÖTH, 1995). A semiótica como ciência estuda toda e qualquer linguagem, seja ela verbal ou não verbal, e seu objeto de estudo é a análise de todo e qualquer fenômeno que seja capaz de produzir significação e sentido. 
As categorias, primeiridade, secundidade e terceiridade, são as mais presentes em todo e qualquer fenômeno, quer seja físico ou psíquico. São conceitos simples, aplicáveis a qualquer coisa. "São ideias amplas que devem ser consideradas mais como tons ou finos esqueletos do pensamento do que como noções estáticas ou terminais" (SANTAELLA, 2013, p.36). São dinâmicas, interdependentes, onipresentes. Por serem universais e formais não entram em atrito com outras categorias, não substituem e nem as excluem. Enquanto as duas primeiras categorias são imediações para a consciência, isto é, não envolvem tempo na sua apreensão, a terceira é tipicamente temporal. É esta consciência de tempo que caracteriza a síntese e a aprendizagem (IBRI, 2001).

Além dessa trilogia, primeiridade, secundidade e terceiridade, Peirce apresenta a tríade ícone, índice e símbolo, cujos termos são amplamente utilizados na literatura semiótica. Essa tríade diz respeito primariamente à distinção entre três espécies de entidades semióticas que um signo pode ter, em razão de três espécies de relações em que o signo está para o objeto, como signo desse objeto (SANTAELLA; NOTH, 1998). Essa relação de referencialidade do signo com o objeto determina a natureza do signo e é indispensável ao raciocínio. O signo, como dito, é uma coisa que representa uma outra coisa para alguém e cria um efeito em uma mente em potencial, podendo, segundo Peirce, ser analisado de acordo com suas propriedades internas - seu significado -, de acordo com referência àquilo que indica - sua representação - e de acordo com os efeitos que está apto a produzir nos seus receptores - como interpretação. Por exemplo, a foto de um cavalo, o desenho de um cavalo, a própria palavra 'cavalo' são signos desse animal. E mesmo que se aborde um objeto que não exista, como um unicórnio, essa representação sígnica continua valendo do mesmo modo. Para Peirce (CP, 8.343), signo é:

[...] qualquer coisa que, de um lado, é assim determinada por um objeto e, de outro, assim determina uma idéia na mente de uma pessoa que é mediatamente determinada por aquele objeto. Um signo tem uma relação triádica com seu objeto e com seu interpretante.

Peirce apresenta três tricotomias: a relação do signo com ele mesmo, a relação do signo com o objeto e a relação do signo com o interpretante. 
[...] a primeira, conforme o signo em si mesmo for uma mera qualidade, um existente concreto ou uma lei geral; a segunda, conforme a relação do signo para com seu objeto consistir no fato de o signo ter um caráter em si mesmo, ou manter alguma relação existencial com esse objeto ou em sua relação com um interpretante; a terceira, conforme seu interpretante representá-lo como um signo de possibilidade ou como um signo de fato ou como um signo de razão (PEIRCE, 1977, p. 51).

Para Nöth (1995) a segunda tricotomia, a relação do signo com seu objeto, é a mais importante para a pragmática, que estuda a situação de comunicação e o efeito do signo, de modo que trata das relações entre signo e objeto, resultando na caracterização do ícone, índice, símbolo. Mas, primeiro, para entender determinada relação entre o objeto e o signo é necessário o conhecimento dado pela experiência colateral. Essa é considerada o conjunto formado pelas experimentações e observações do indivíduo, em um entrecorte feito na mente, com a interligação de lembranças e associações, é plausível assegurar que a experiência colateral seria a intimidade prévia de cada interpretante com o objeto em ação, numa espécie de enciclopédia individual de conhecimento a respeito de determinado assunto, reunido durante a vida. Peirce denomina de experiência colateral "uma prévia familiaridade com aquilo que o signo denota" (CP 8.179), ou seja, ao que evocamos como conhecimento necessário para entender, completar e fortalecer a compreensão da relação do objeto com o signo.

Para que o signo suscite determinado significado na mente de uma pessoa, torna-se necessário que ela tenha um conhecimento prévio sobre o objeto retratado no signo. Dependendo desse conhecimento, o significado suscitado vai mudar. Pela generalidade do signo, este apresenta dificuldades ao tentar representar o objeto, por se aproximar apenas de uma parte dele e não do todo. A experiência colateral do objeto contribui para que seja minimizada a incompreensão de alguns aspectos do signo, tendo como principal função a de complementar e fornecer um componente a mais na busca da compreensão.

Dito isso, explicitaremos as relações entre signo e objeto caracterizados pela tríade: ícone, índice, símbolo. O ícone participa da primeiridade por aparecer como simples qualidade na sua relação com seu objeto. Isto porque qualidade não representa, ela se apresenta e, dessa forma, os ícones são capazes de produzir as mais imensuráveis relações de comparação. Assim, "o objeto do ícone 
é sempre uma possibilidade do efeito de impressão que ele está apto a produzir ao excitar nosso sentido" (SANTELLA, 2007, p.64). Para esta autora, os ícones têm um alto poder de sugestão, de fato, qualquer qualidade tem. Por isso apresenta condições de ser um substituto de qualquer coisa que se assemelhe e assim, no universo da qualidade, as semelhanças proliferam. $O$ signo representa o seu objeto por semelhança e, sendo assim, como mera qualidade pertence à primeiridade.

O índice, como o próprio nome alude e por estar diretamente ligado ao objeto, indica alguma coisa, tendo como fundamento a existência concreta deste. Ele é designativo de algo existente. A terra molhada nos remete ao fato de que choveu, pegadas na areia prontamente nos transmitem a ideia de que alguém passou por ali, fumaça é indicativo de fogo. Tudo o que existe é um índice ou pode funcionar como um. Assim, temos aqui uma relação de causa e efeito. Para agir indicialmente, "o signo deve ser considerado no seu aspecto existencial como parte de um outro existente para o qual o índice aponta e do qual o índice é uma parte" (SANTAELLA, 2005, p.20). Todos os índices envolvem ícones. A relação de semelhança na foto remete para um ícone, mas remete para um índice, quando é resultado de uma conexão ou relação de fato entre a foto e o objeto real. O índice é um signo que estabelece relações diádicas entre representamen e objeto, por isso participa da secundidade, "relações [que] têm o caráter de causalidade, espacialidade e temporalidade" (Nöth, 1995, p.82). Logo, o índice é um signo que age como um indicador, que se concatena eficazmente com o objeto, por proximidade e associação. É ele que desperta a atenção num objeto, por meio da consequência e aproximação entre duas experiências ou duas porções de uma mesma experiência. Ele "força o olhar do receptor a se virar para o objeto, compelindo o intérprete a ter uma experiência" (SANTAELLA, 2012, p.123).

O símbolo pertence à segunda tricotomia, que participa da categoria da terceiridade, pois depende de convenções sociais, leis ou associação de ideias gerais. Segundo Peirce (1977, p.52; CP 2.249), "um símbolo é um signo que se refere ao objeto que denota em virtude de uma lei, normalmente uma associação de ideias gerais que opera no sentido de fazer com que ele seja interpretado como se referindo àquele objeto". O símbolo é apenas mediação, um meio geral para o desenvolvimento de um interpretante, e, por ser portador de virtudes, como generalidade da lei, regra, hábito ou convenção, sua função como signo dependerá precisamente dessa lei ou regra que determinará seu interpretante (SANTAELLA, 2012). Resumidamente: 
O ícone não tem conexão dinâmica alguma com o objeto que representa; simplesmente acontece que suas qualidades se assemelham às do objeto e excitam sensações análogas na mente para a qual é uma semelhança. Mas está realmente desconectado do seu objeto. O índice está fisicamente conectado com seu objeto; formam ambos, um par orgânico, porém a mente interpretadora não tem nada a ver com esta conexão, exceto o fato de registrá-la, depois de ser estabelecida. O símbolo está conectado com seu objeto por força da idéia da mente que usa o símbolo, sem a qual tal conexão não existiria (PEIRCE, 1977, CP2.299).

O ícone pertence à primeiridade por uma qualidade, possibilidade. Qualifica-se em relação ao objeto por traços de semelhança ou analogia. O índice está na secundidade por um existente, refere-se ao objeto por ser afetado por ele, decorre de uma relação de causalidade. Já o símbolo concerne à terceiridade por se referir a uma lei, regra ou convenção. Mantém uma relação cultural e arbitrária com o referente. Talvez possamos compreender melhor essas três categorias em um processo contínuo: uma pessoa, que não conhece o Brasil nem nossa cultura política, pode ver na foto de um tucano um ícone, identificando-a apenas como a ave tucano; um biólogo, ao ver a foto, poderá vê-la como índice, relacionando-a com um representante das aves; um político veria a foto como um símbolo, ou seja, como representante de um partido político. Nesses casos, temos a mesma foto vista como ícone (semelhança), índice (existente) e símbolo (convenção) em três situações diferentes.

As categorias fenomenológicas e a relação entre o signo e objeto apresentado formam a base para a construção do instrumento de análise da pesquisa, que visa estudar a gesticulação dos estudantes. A partir de uma reinterpretação da semiótica peirciana, construímos o nosso instrumento de análise, denominando as gesticulações de Gesticulação Icônica, Gesticulação Indicial e Gesticulação Simbólica. Esses signos nos permitiram classificar os estudantes em categorias de Primeiridade, Secundidade e Terceiridade. Para isso levamos em consideração a experiência colateral do estudante, que "constitui o pré-requisito para conseguir qualquer ideia significada do signo. Observação colateral refere-se à intimidade prévia com aquilo que o signo denota" (PEIRCE, C.P. 8.179).

\subsection{Ferramenta de Base para a Análise da Gesticulação}


As análises das gesticulações tomaram a clássica diferenciação dos signos em índices, ícones e símbolos de Peirce $(1977,2.299)$. Queremos deixar claro que fizemos uma reinterpretação, tomando por base uma leitura de Peirce. Isso significa que, em referência às definições de Peirce, elaboramos uma mudança, adequando-as à nossa análise. Não obstante, dado que o contexto de interesse é pedagógico e circunscrito à gesticulação, os referidos critérios estarão direcionados para esse interesse e, assim, um afastamento stricto sensu dos seus sentidos se faz necessário.

Peirce relaciona a primeiridade com as ideias do acaso, uma qualidade, o primeiro contato. Corresponde à noção de acaso, começo, indeterminação, vagueza, indefinição, possibilidade, originalidade irresponsável e livre, imediaticidade, qualidade de aparência, sem referência a qualquer coisa, presença imediata do irrefletido, como por exemplo, a capacidade contemplativa dos estudantes quando observavam os materiais de laboratório de química como eles realmente eram, sem substituí-los por nenhuma interpretação ou sem relacioná-los a alguma coisa, tais como não relacionar a bureta à titulação. É a qualidade que se apresenta, isto é, a primeiridade. A secundidade relaciona-se com as ideias de ação e reação, conflito, dependência, dualidade, aqui e agora. Por exemplo, no momento em que o aluno, no laboratório, relacionou os materiais aos procedimentos e a atividade experimental a um conteúdo, seja esse a causa da atividade ou não, estava em secundidade. Já a terceiridade está ligada às ideias de generalidade, representação, continuidade, crescimento, aprendizagem, mediação, inteligência, lei (SANTAELLA, 2013). Na situação das atividades de ensino pesquisada, seria o momento que o aluno relacionou o resultado da atividade prática ao conteúdo, conseguiu entender o que aconteceu devido à sua experiência colateral e a resolução de atividades de forma multimodal do conteúdo em questão. Portanto, estava em terceiridade.

Peirce denomina de experiência colateral "uma prévia familiaridade com aquilo que o signo denota" (CP 8.179), ou seja, é a busca do conhecimento anterior necessário para entender, completar e fortalecer a compreensão da relação do objeto com o signo. Sendo assim, a experiência colateral do objeto, contribui para que seja minimizada a incompreensão de alguns aspectos do signo. Para nós, a relação significativa do estudante com o experimento se dará por meio da experiência colateral, ou seja, seus conhecimentos anteriores, os pré-requisitos, a aula relativa àquele conteúdo que estava sendo aplicado na atividade. Podemos relacionar, por exemplo, a memória. Ela faz a relação entre aquilo que o aluno está vendo, por exemplo, os 
materiais de laboratório, e algo que foi aprendido anteriormente a respeito do uso, da função daquele material. Para que isso acontecesse, o estudante suscitou os conhecimentos prévios, ou seja, sua experiência colateral.

Por exemplo, ao ser pedido a um estudante que pegue um frasco de reagente com determinada concentração para preparar um experimento de concentração de soluções, estando dois frascos de concentrações diferentes a sua frente, ele gesticula, mostrando não saber distinguir a diferença entre os dois dentro do contexto "atividade prática de química a respeito de concentração de soluções", a ação do estudante demonstra que ele está em primeiridade, pois ainda não consegue relacionar a fórmula escrita no frasco ao conteúdo de química estudado. Dessa forma, a ação do estudante é um signo e pode ser interpretada e analisada pela professora como um indício de aprendizagem ou não. Para esta categorização, utilizamos as gesticulações produzidas pelos estudantes na realização das atividades de ensino e, baseados na leitura da semiótica de Peirce, chamamos estas gesticulações de indiciais, icônicas ou simbólicas, de acordo com o momento estudado.

De acordo com a atividade de ensino desenvolvida no laboratório, se a ação de comunicar do estudante traduziu-se apenas em uma simulação, repetição, ou seja, repetição de ordens expedidas pelos colegas, a sua gesticulação encontrava-se tomada pelo princípio da imitação, quer seja da ação do colega ou da cópia do caderno de outro. Visto que não foi analisada, a emissão de signos foi do tipo Gesticulação Icônica. Neste caso, as gesticulações surgidas da cópia visual de ações mecânicas dos colegas, do professor ou de receituários verbalizados de outros ou lido em manuais, sem demonstração de autonomia, colocou-o numa situação de primeiridade. 0 estudante ainda vê o conteúdo e o experimento como uma qualidade daquilo que é, sem reflexão.

Um índice tem um emissor e um intérprete, mas não um comunicador, portanto, antes de comunicativo ele é um signo primeiramente expressivo, segundo a terminologia de Eco (1985). Na ocorrência de gesticulações arbitrárias, fica estabelecida uma conexão pseudocausal entre a ação do sujeito e a situação empírica que foi por ele enfocada na atividade instrucional realizada. Em termos semióticos, isto quer dizer que inexistiu uma vinculação de causa e efeito entre o significante e o significado dos signos demonstrados por meio das gesticulações. Em outras palavras, os signos se mostraram incorretos e sem que houvesse uma relação do que foi expresso 
pelas gesticulações com o significado do conteúdo científico. Neste caso, as gesticulações foram denominadas de Gesticulações Indiciais e estavam relacionadas à secundidade, ou seja, existiu uma relação dual, mas não adequada ao conteúdo da atividade de ensino, porque se estivesse adequada seria terceiridade

Contrariamente, quando a ação de comunicar, durante a gesticulação, fosse intencional e obedecesse a um acordo institucional entre professor e aluno, já que a mesma se encontrava sob fundamentos de convenções científicas, então, os signos emitidos por ela foram considerados símbolos, sendo chamados de Gesticulação Simbólica. Estes, ao se virem representados nas ações, foram produto de ensino e o plano das suas expressões se ligou ao plano dos conteúdos científicos, numa relação causal entre significantes e significados, portanto, terceiridade. De fato, as corretas ações empíricas, quando assim consideradas, incorporam símbolos institucionalizados pela ciência que conduzem a ações objetivas e únicas cientificamente válidas.

É possível visualizar as relações sobre as quais nosso trabalho foi desenvolvido. O experimento é uma representação dentre muitas outras aplicadas na introdução e desenvolvimento de conteúdos químicos, que auxiliam e complementam a construção dos processos e conceito científicos. O experimento apregoou o conhecimento do estudante referente ao conteúdo e a gesticulação foi a expressão semiótica pela qual a pesquisadora observou a relação do experimento com o conhecimento do conteúdo.

Figura 1. Representação do objeto (conteúdo) e os signos (gesticulações) que nos permitirá a análise.

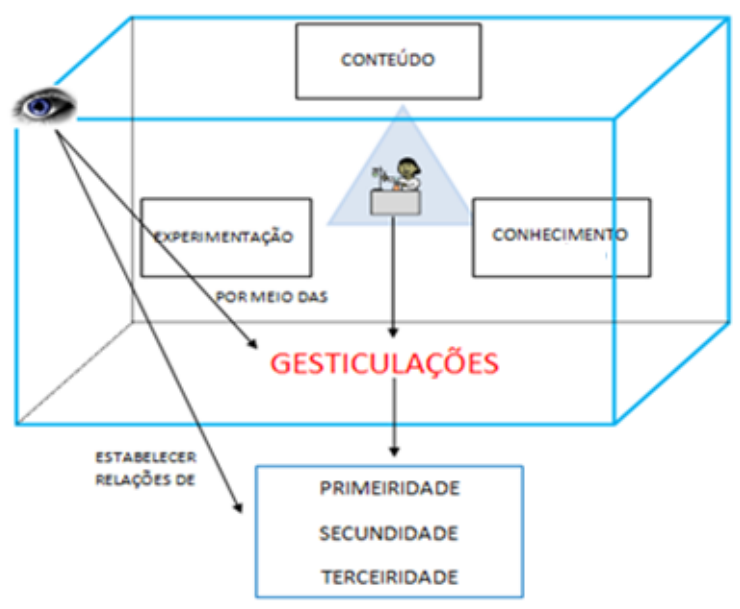

Fonte: dados da pesquisa. 
Dados os elementos semióticos que ocorrem no laboratório, demonstrado pela figura acima (Figura 1), o sistema semiótico peirciano reinterpretado por nós funciona da seguinte forma: ao fundo está a experimentação, conteúdo visto (experiência colateral) e conhecimento. O fundamento/signo (a) do laboratório é a experimentação. Já o objeto (b) do laboratório, é variável e pode se apresentar de algumas formas, conforme o que se pretende estudar. Ele seria representado pelo conteúdo (objeto), que teria como experiência colateral o mesmo conteúdo visto em sala de aula. Por fim, o interpretante (c) é a pulsão significativa que a relação entre signo e objeto, relacionada pelo estudante, traz à tona, o conhecimento, ou seja, é nessa relação signo/objeto (experimentação/conteúdo-experiência colateral) que pudemos observar o processo desenvolvido pelo estudante para se chegar ao conhecimento. Esta relação do signo com seu objeto é observada e analisada por meio das gesticulações produzidas no desenvolvimento da atividade de ensino. As gesticulações icônicas, indiciais e simbólicas foram os signos produzidos pelos estudantes e a investigadora (olho) que se encontra fora do triângulo que observa a relação signo/objeto produzidas pelas gesticulações dos estudantes para, então, categorizá-los em primeiridade, secundidade e terceiridade.

Interpretar a gesticulação de um sujeito não consiste em uma empreitada precisa para quem interpreta, por isso, tentar encontrar o máximo de sentido que existe atrás dela é um desafio. Olhar a gesticulação é procurar decifrar sua linguagem, como processo, como índice de cognição e buscar referenciais para sua análise. Sua dinâmica e sua interatividade trazem para o âmbito da pesquisa campos de visibilidade ainda inexplorados. É esta visibilidade fenomenológica que permitirá a compreensão da linguagem por meio da gesticulação. A semiótica pode ajudar a interpretar, entender, traduzir essas gesticulações levando em conta não somente aspectos relacionados ao conteúdo da experimentação em si, mas aspectos subjacentes a conteúdos necessários para que se tornem possíveis as interações entre conteúdos passados e atuais. 0 estudo a respeito da semiótica é no sentido de relacionar a leitura dos signos baseados nas gesticulações e que informações elas passam sobre a aprendizagem dos estudantes de conceitos envolvidos nas atividades de laboratório de química. 


\section{PROCEDIMENTOS METODOLÓGICOS}

\subsection{Coleta e amostra}

As gesticulações dos estudantes foram obtidas por meio de videogravação e anotações de campo, feitas pela pesquisadora. Ao final das gravações, assistimos aos vídeos repetidas vezes para a tomada de dados, com recortes dos instantes mais expressivos da gesticulação, o que resultou em frames $^{2}$. As anotações do caderno de campo foram utilizadas na tentativa de balizarmos a direção de algumas interpretações consideradas importantes, ou seja, as anotações complementaram as gravações com detalhes escritos pela pesquisadora, como apontamentos a respeito de decisões dos professores e estudantes, reações imprevistas, formas de lidar com dificuldades dos estudantes e outros aspectos que corroboraram as imagens do vídeo. O trabalho foi realizado em uma escola pública, no período noturno, entre os anos 2012 e 2013. Participaram do estudo os estudantes do curso técnico em química do 20 e 3ำ ciclo. Esse curso tem a duração de dois anos e só podem se matricular aqueles que concluíram o Ensino Médio, por isso é chamado de Subsequente. Os estudantes analisados foram escolhidos por conveniência pela pesquisadora por serem aqueles que melhor se pôde observar nas filmagens e na observação em sala.

Os estudantes já tinham visto, não só os conteúdos concentração e diluição de soluções e oxirredução, como todos os outros conteúdos do Ensino Médio. A escola dispunha de diversos recursos didáticos para auxiliar os estudantes na aprendizagem, como três laboratórios de ciências (física, química e biologia), laboratório de informática, salas de aula equipadas com TV pendrive e DVD, projetor multimídia e biblioteca. Os laboratórios possuíam laboratorista, que auxiliava os professores antes, durante e depois das práticas. Para realizarmos o estudo, recorremos à direção da escola e à laboratorista. Após permissão, a laboratorista entrou em contato com os professores e a pesquisadora explicou que suas aulas seriam filmadas para futura análise. Os estudantes concordaram com a filmagem ao saberem que não seriam identificados.

\subsection{Procedimento para análise dos significados das gesticulações}

Todo material produzido pela videogravação, inclusive as anotações da pesquisadora, foram analisados para separar as atividades de ensino nas quais as gesticulações foram interpretadas e,

\footnotetext{
${ }^{2}$ O frame representa uma pequena parte do vídeo, ou seja, é cada um dos quadros ou imagens fixas de um vídeo.
} 
também, para a montagem dos frames.Como o frame representa uma pequena parte do vídeo, descrevemos o que ocorreu neles, enfocando o que pretendíamos mostrar, em seguida, fizemos a análise. Os frames não têm intervalos de tempo fixos, são instantes mais representativos dos momentos/da gesticulação em análise. Nos frames, os rostos foram parcialmente cobertos com uma faixa para preservar o anonimato dos participantes. Cada estudante do grupo recebeu um nome como A1, A2 e assim por diante a fim de facilitar a identificação do/da estudante da gesticulação em análise.

Para a análise das gesticulações, fizemos a descrição como ocorreram, no decorrer da atividade de ensino, num primeiro momento. No segundo momento, fizemos a interpretação das gesticulações desses estudantes de acordo com o instrumento de análise. Os "frames omitidos", citados na descrição e análise dos dados, fizeram referência a gestos e ações ocorridos na atividade de ensino, vistos pela pesquisadora, que não foram apresentados nesta tese.

\subsection{Instrumento de análise e a avaliação processual}

As reflexões a respeito dos gestos podem ser diretamente estendidas para a gesticulação. Como dito, esta compõe uma linguagem corporal de natureza representacional. Do ponto de vista da importância pedagógica, e baseando-nos nas considerações precedentes, a gesticulação sintetiza duas dimensões a serem atendidas: uma cognitiva, haja vista seu papel auxiliar na construção do pensamento e na elaboração do significado daquilo que o aprendiz está estudando; outra, de maior interesse neste trabalho, de natureza avaliativa processual, visto se constituir em uma linguagem que permite ao professor apreciar o significado do conhecimento do que está sendo construído pelo estudante.

Por avaliação processual, também denominada de avaliação formativa ou contínua, designamos um instrumento permanente de trabalho docente que permite acompanhar o processo de ensino e aprendizagem e serve como base para criar um diagnóstico das dificuldades futuras, permitindo resolver situações presentes. A avaliação processual também permite a reflexão, tanto dos estudantes como dos professores, a respeito do nível de qualidade do trabalho escolar gerando mudanças significativas (HOFFMANN, 2009; GIL, 2006; MIZUKAMI, 1986; VASCONCELLOS, 1995; GRILLO, 2003; LUCKESI, 1997, 2006). De acordo com os autores, a avaliação processual (formativa ou contínua), agregada ao processo de construção do conhecimento dos estudantes, tem a 
finalidade de proporcionar informações acerca do desenvolvimento do processo de ensino e aprendizagem. Ela contribui para o entendimento de uma avaliação sem finalidade seletiva, com vistas a redefinir prioridades e ajuste de estratégias, a fim de perceber as dificuldades dos estudantes, com o propósito de orientar, apoiar, reforçar e corrigir os estudantes para que superem suas dificuldades e percebam seus progressos. Portanto, a avaliação processual permite compreender o contexto da aprendizagem, analisar suas modalidades, mecanismos e resultados. Da observação, passa-se à intervenção, por se pressupor a reflexão referente à construção do estudante na elaboração do conhecimento científico e se direciona as intervenções com o intuito de se chegar aos resultados efetivamente desejados.

\section{RESULTADOS E DISCUSSÃO}

Foram analisados dezesseis estudantes para a tese. Apresentamos uma atividade, mas nas discussões apresentaremos os dados completos da pesquisa.

\section{Reação de Óxido-Redução}

O objetivo da atividade foi reconhecer as reações ocorridas como reações de oxidorredução. Para isso, os estudantes deveriam preparar, conforme o manual de procedimento, uma solução de ácido clorídrico, adicionar duas ou três substâncias ao tubo de ensaio, observar e anotar o que aconteceu, ou seja, se houve ou não reação de oxirredução. A análise desta atividade está dividida em duas partes: a) separação dos reagentes e b) coleta dos reagentes e observação das reações. Os frames apresentados são parte de uma pesquisa maior de tese de doutorado. Devido a isso, neste artigo, a numeração dos frames iniciam em 14 e segue até a 34.

\section{a) Separação dos reagentes a serem utilizados}

\section{Descrição da gesticulação}

Após a preparação da solução de ácido clorídrico, os grupos coletaram os reagentes para as próximas etapas. Os reagentes encontravam-se na bancada principal, todos identificados por suas fórmulas químicas, colocados em vidros grandes, quando soluções, e em frascos menores, quando sólidos, tornando fácil a visualização dos reagentes pelos estudantes. Era necessário pôr um pouco das soluções e dos reagentes sólidos em um béquer ou em um frasco menor para manuseá-los. 
Os dois grupos foram para a bancada central (figura 2, frames 14 e 15) coletar os reagentes. A2 e A1 leem o procedimento (frame 16 e 17), procuram os materiais que estão faltando e A2 começa a colocar os reagentes nos tubos de ensaio.

Figura 2. Frames 14 a 17: coleta de reagentes.
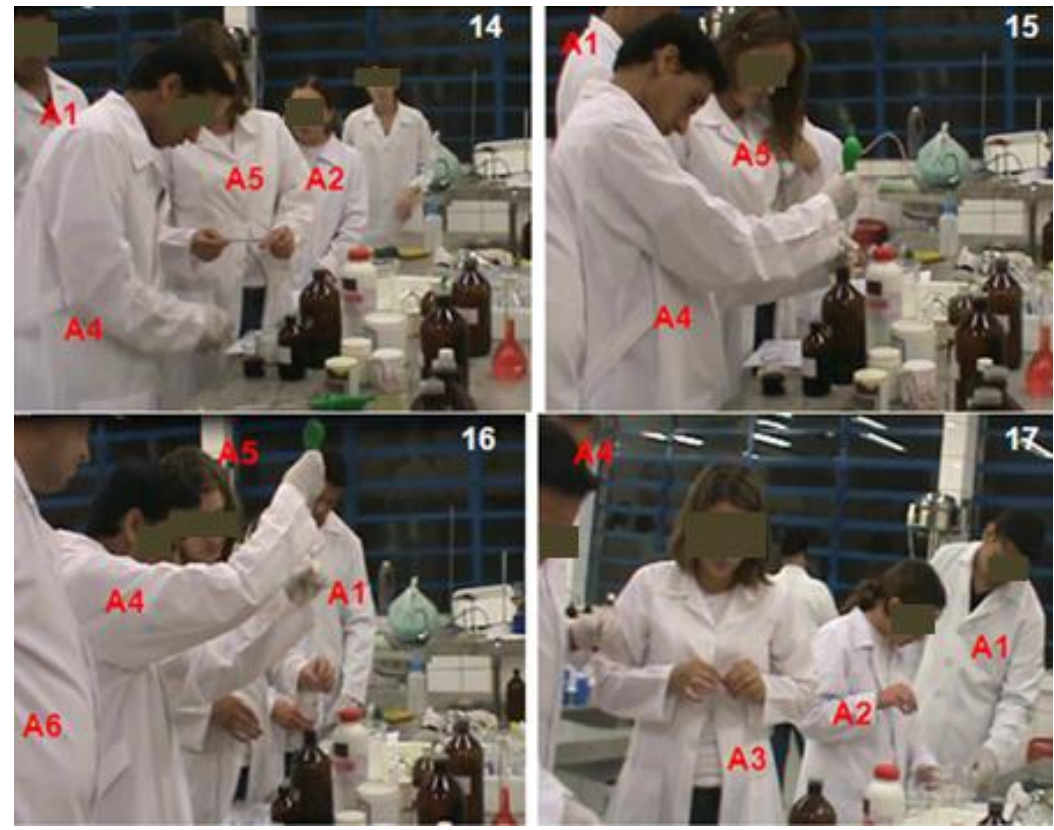

Fonte: dados da pesquisa.

Na figura 3 podemos ver que os integrantes dos dois grupos foram à procura de uma solução e não a identificaram entre os reagentes (frame 18). Houve uma conversa entre eles acerca da identificação do frasco (frames omitidos) e A5 chamou o professor enquanto seus colegas continuaram a procura. Em seguida, o professor chegou e apontou para o frasco que continha o reagente que estavam procurando (frame 19). Então, eles separam os reagentes (frames omitidos) e continuaram a coleta. Alguns em frente à bancada coletaram os materiais e os outros componentes ficaram sentados esperando a chegada dos colegas.

Figura 3. Frames 18 a 21: auxílio do professor à coleta de reagentes. 

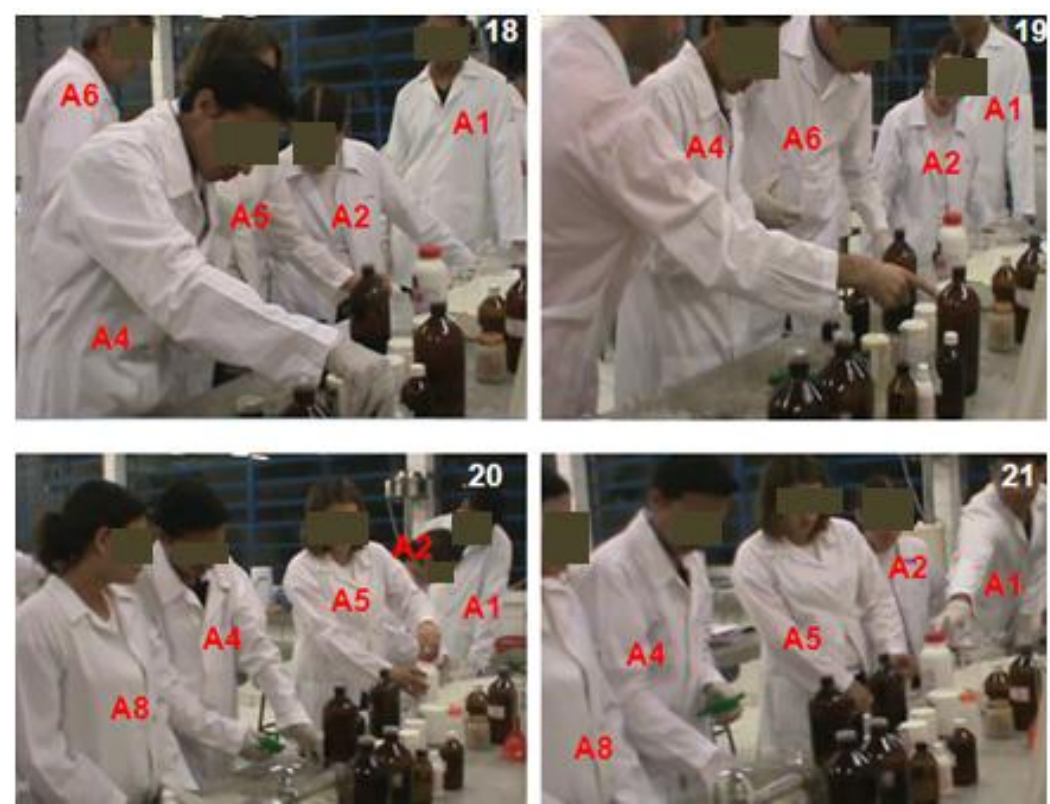

Fonte: dados da pesquisa.

\section{Interpretação das Gesticulações}

\section{Estudantes A1 e A2}

Os nomes dos reagentes, no manual de procedimentos, foram registrados por extenso, enquanto nos frascos estavam representados por suas fórmulas químicas. Observando as gesticulações de A1 e A2, vimos que eles aparentavam ter algum conhecimento das fórmulas químicas (frames 16 a 17), pois não conseguiram reconhecer apenas uma das soluções, a de ácido nítrico. Essa não foi uma dúvida apenas desses dois estudantes, visto que A4, A5 e A8, que estavam na bancada, também não encontraram o ácido, como já afirmamos anteriormente.

Suas experiências colaterais não colaboraram com a identificação do ácido nítrico por meio de sua fórmula molecular. As informações a respeito de representação das substâncias por meio de fórmulas químicas, sua nomenclatura e a formulação de ácidos, em anos anteriores, no ensino regular e depois, no curso subsequente técnico em química, não foram suficientes para que tivesse ocorrido a aprendizagem do assunto. Assim, nem ocorreu a ideia aos estudantes A1 e A2 de que poderiam ter encontrado o frasco por exclusão e daí, talvez, perguntado ao professor se aquele era o frasco correto. O gesto dêitico do professor (figura 6, frame 19) permitiu o reconhecimento do ácido e a continuidade do trabalho. (De fato, pelas duas equipes: grupo 1 A1, A2, A3 e grupo $2-A 4, A 5, A 6)$ 
As gesticulações indiciais dos estudantes, nos frames de 16 a 19, os colocam em secundidade, porque os signos da fórmula e do nome se associam, ou seja, apontam em direção ao reconhecimento ou não das fórmulas e seus respectivos nomes. Na secundidade há uma relação dual que apresenta uma conexão com aquilo que indica. Portanto, as gesticulações, os frascos de reagentes que foram pegos e devolvidos pelo estudante, juntamente com as anotações de campo, fizeram com que, neste caso, concluíssemos que as gesticulações dos estudantes indicavam uma falha na aprendizagem do conteúdo "representação das substâncias por meio de fórmulas químicas", ou seja, não a reconhecem/identificam determinadas fórmulas químicas.

\section{b) Coleta dos reagentes e observação das reações}

\section{Descrição de gesticulação}

Como podemos ver na Figura 4, os estudantes A1 e A2, do Grupo 1, foram coletar os materiais na bancada central, uma estudante não participou das atividades e a outra ficou esperando pelos colegas na bancada enquanto copiava as questões a serem apresentadas no relatório. A1 e A2 coletaram as soluções, mas não misturam os reagentes e levaram tudo para a bancada.

Figura 4. Frames 22 e 23: coleta de reagentes pelo Grupo 1.
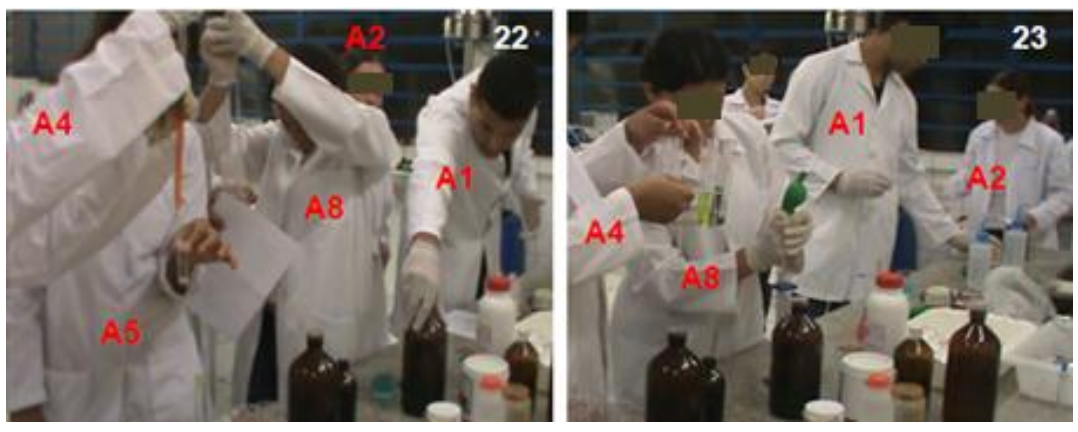

Fonte: dados da pesquisa.

Os componentes do Grupo 2 coletaram os reagentes e os misturaram às soluções. De acordo com a explicação do professor e com o manual de procedimento do experimento, o objetivo era observar se ocorreria reação ou não. A pressa com que queriam preencher todos os tubos de ensaio impossibilitou a observação imediata, por isso não foram aqui analisados. 
Na figura 5 , vemos que $A 1$ e $A 2$ tinham a sua frente os tubos de ensaio para colocar os reagentes. A1 começou por colocar água em um tubo (frame 24), ele e A2 leram as instruções (frame 25), pegaram a solução de sulfato de cobre e, enquanto A1 pipetou-o em três tubos de ensaio (frame 26), A2 colocou a limalha de ferro em outros três tubos (frame 25).

A1 pegou um balão volumétrico com uma solução de dicromato de potássio (frame 27) e pipetou em dois tubos de ensaio (frames omitidos). A solução de ácido sulfúrico e de permanganato de potássio foi pipetada por A4 (ver no frame 23), integrante do outro grupo.

Figura 5. Frames 24 a 27: coleta dos reagentes e água nos tubos de ensaio
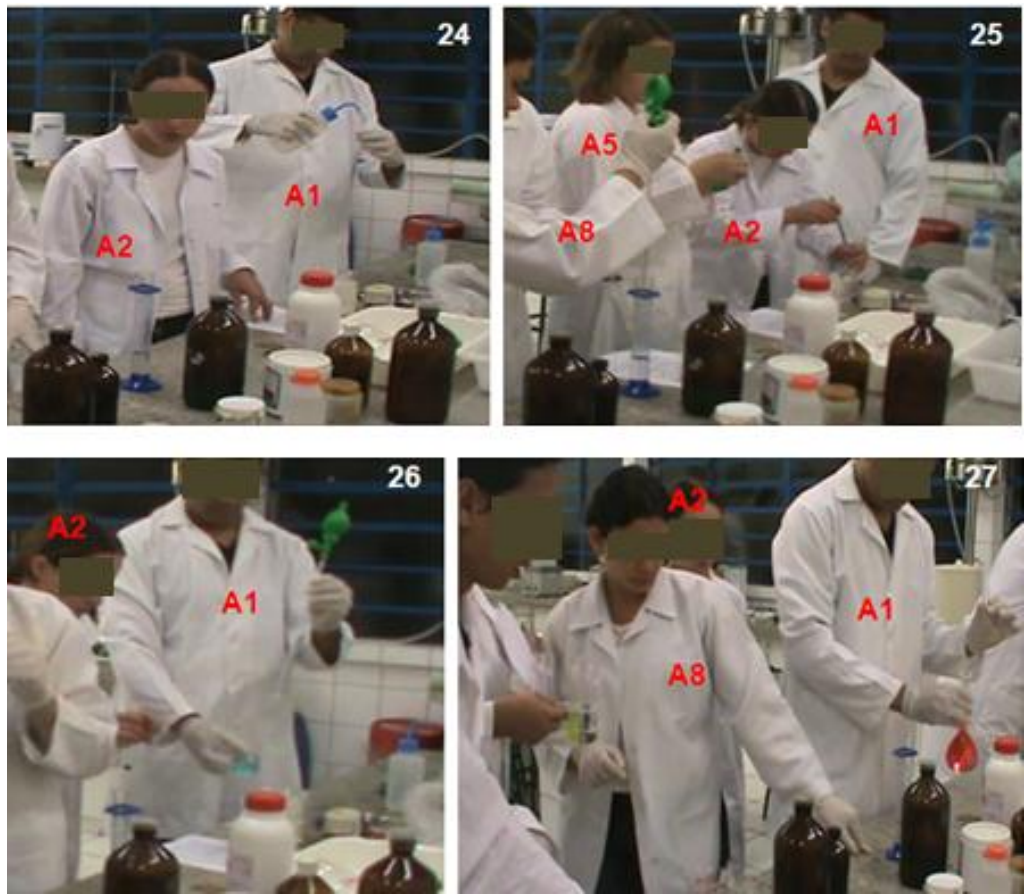

Fonte: dados da pesquisa.

Em seguida, A1 e A2 foram para a mesa e se juntaram a A3, terceira integrante do grupo. Enquanto $\mathrm{A} 2$ e $\mathrm{A} 3$ reliam os procedimentos, $\mathrm{A} 1$ começou a pipetar a solução de ácido clorídrico nos tubos de ensaio (figura 9, frame 29).

Figura 6. Frames 28 e 29: término da coleta e retorno à bancada. 

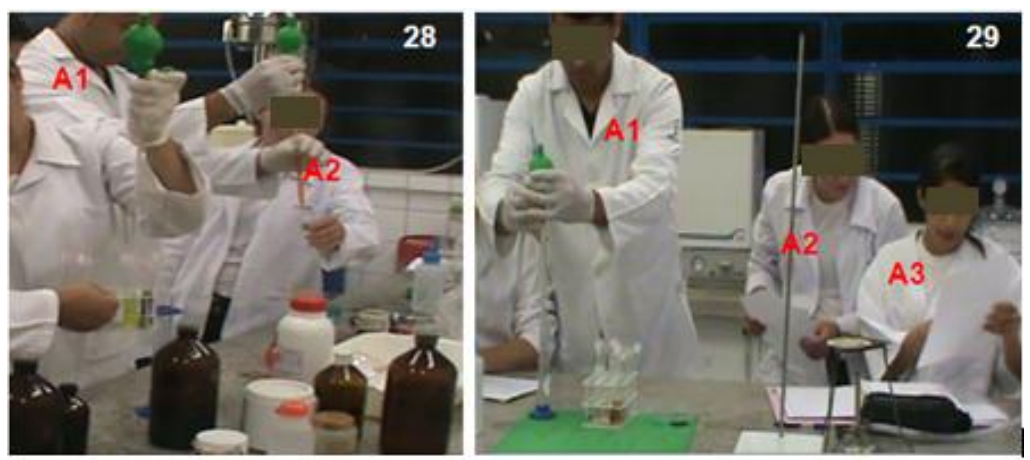

Fonte: dados da pesquisa.

A seguir, na Figura 10, o frame 30 deixa ver que A1 e A2 pegaram os tubos, observaram e A3 anotou suas observações. A1 segurou o tubo de ensaio entre as mãos, a solução borbulhava, então A2 iniciou uma ação de juntar os dedos, abrindo-os e fechando-os repetidamente, explicando a A3 o que estava acontecendo (frame 31). A1 terminou de adicionar água oxigenada nos tubos onde faltava o reagente e A2 pegou os tubos para observá-los sob o olhar de A3 (frames 32 e 33), que escrevia o ocorrido.

Figura 7. Frames 30 a 34: análise das reações.
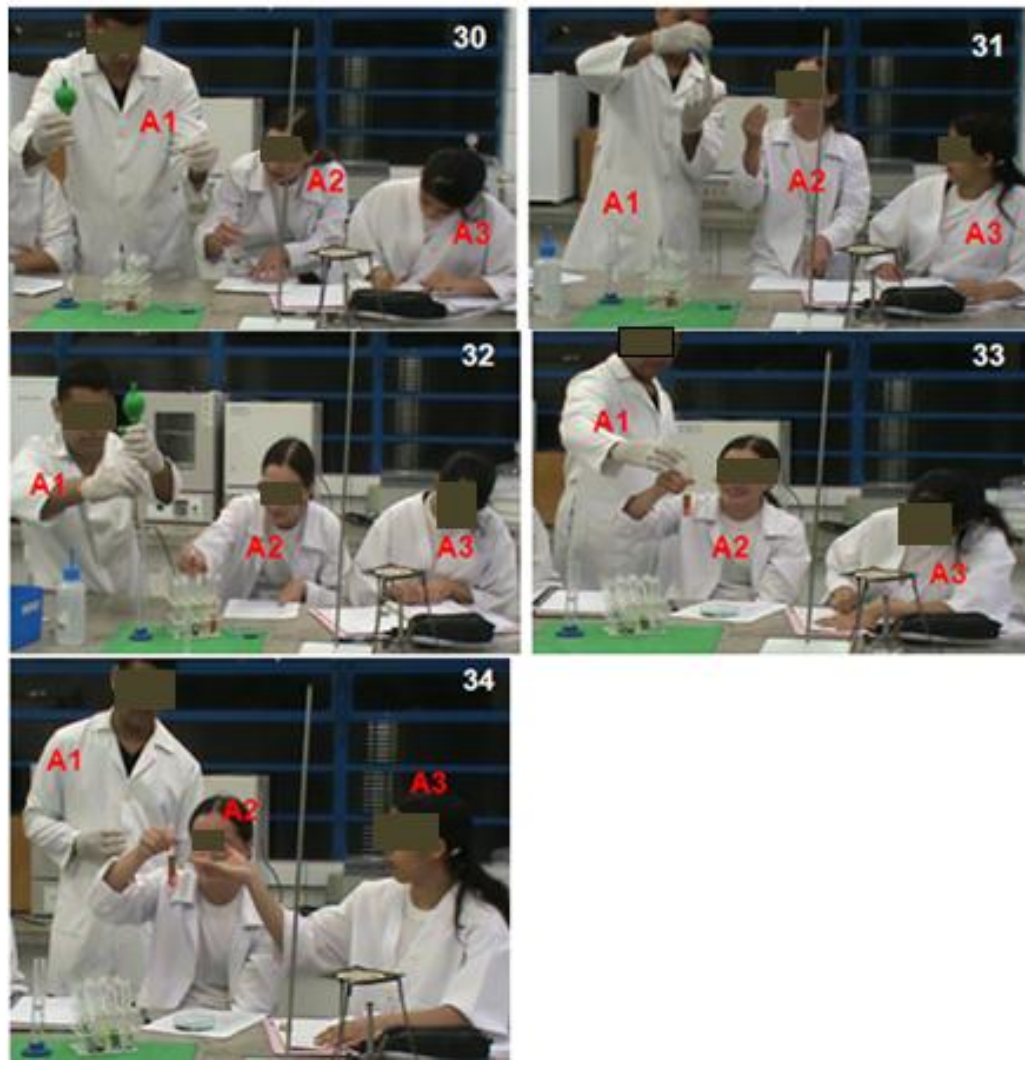
Fonte: dados da pesquisa.

A2 segurou o tubo, contendo a solução de dicromato de potássio e solução de ácido sulfúrico, enquanto $\mathrm{A} 1$ adicionou um pouco de álcool, a pedido do professor, e os três observaram o que aconteceu (frame 33). A3, com a mão estendida, fez gestos de sobe e desce na vertical, referindose ao que estava acontecendo com a coloração no tubo (frame 34).

\section{Interpretação dos significados}

\section{Estudantes A1 e A2}

As observações das gesticulações indicam que os estudantes A1 e A2 tinham pelo menos a noção de reação, pois eles não colocaram todos os reagentes nos tubos de ensaio de uma só vez. As gesticulações indiciais, mostradas nos frames de 31 a 34, caracterizam a secundidade, que é dualidade, ação e reação entre o experimento e seu efeito, ou seja, o que vai acontecer entre a conclusão que deveria ter sido extraída do experimento e o conteúdo. Isso é explicado pelo momento em que A1 e A2 esperaram para terminar de adicionar os reagentes só após sentarem e observarem o que aconteceu nos tubos, juntamente com a terceira integrante do grupo.

A adição da solução de ácido clorídrico à solução de permanganato de potássio, no tubo 2, fez com que a reação ocorresse, observada pela mudança de cor (frame 30) e a adição da solução de ácido clorídrico à limalha de ferro, no tubo 6, fez com que a reação ocorresse com desprendimento de gás hidrogênio, como anotamos em nosso caderno de bordo. As gesticulações de A2 (Figura 10, frame 31 e omitidos), com a repetição contínua do abrir e fechar dos dedos, revelou signos simbólicos, porque essas gesticulações permitiram a A2 comunicar o conhecimento do conceito de reação para A3.

Dessa forma, foi possível categorizar A2 em terceiridade nessa gesticulação, visto que sua experiência colateral permitiu a seguinte interpretação: quando misturamos dois reagentes diferentes e há mudança de cor, efervescência ou precipitação, isso evidencia uma reação química.

Estudante A3 
A adição de água oxigenada à solução de cloreto ferroso, seguida pela adição de ácido clorídrico, no tubo 4, também foi uma reação que ocorreu com a mudança de coloração. 0 mesmo aconteceu no tubo 5, quando misturadas a solução de dicromato de potássio, água oxigenada e solução de ácido sulfúrico (frames omitidos). Essas mudanças foram anotadas por A3 sem discussão, que escreveu o que os colegas falaram. No tubo 10 (Figura 10, frame 33), a solução de dicromato de potássio, juntamente com a solução de ácido sulfúrico, manteve a coloração laranja até ser adicionado o álcool, a coloração então mudou para verde, indicando uma reação de oxidação, tendo como produto um aldeído. Com o balançar das mãos, A3 tentou entender o que aconteceu, o que foi explicado verbalmente por A2.

Pela pouca participação de A3 no decorrer da aula, pelo que observamos das suas gesticulações icônicas e pela sua participação no grupo, afirmamos que A3 apresenta dificuldades de aprendizagem no conceito de óxido-redução, nos conteúdos de concentrações de soluções, nas regras de segurança e no uso de materiais de laboratório. Nesse sentido, é importante relatar que A2 sempre estava por perto, auxiliando no cálculo da quantidade de volume de ácido clorídrico para a preparação da solução e nas anotações das observações das ocorrências nos tubos de ensaio. Afirmamos que os signos relacionados a A3 foram icônicos, porque foram atos mecânicos que não indicam uma aprendizagem de fato, o que o coloca, nesse instante, na categoria da primeiridade, pela semelhança da fala à dos colegas e as anotações que realiza e a não correspondência entre o conteúdo e o que acontece no experimento.

As gesticulações de A1 e A2 mostram que os dois possuem técnicas e destrezas válidas e revelam muito sobre seus conhecimentos. A1 e A2 apresentaram adequada compreensão sobre os conceitos de soluções, concentração de soluções e de reações. Ao coletarem os reagentes, não os colocaram todos de uma só vez nos tubos de ensaio, esperaram para adicionar o segundo reagente, quando pudessem observar. Como todas as reações eram de óxido-redução, evidenciadas pela mudança de cor ou pela liberação de gás, não foram percebidas pelos estudantes durante a aula devido à lentidão. Duas, em particular, a do tubo 1 (alumínio e solução de sulfato de cobre) e a do tubo 7 (limalha de ferro e água), eram reações muito lentas e por isso também não foram presenciadas. 
Além da mudança de cor ou liberação de gás, havia necessidade de conhecer a tabela de reatividade dos metais para fazer o cálculo do número de oxidação e verificar se houve perda e ganho de elétrons. Isso não aconteceu. As anotações in loco dos estudantes com relação a esses dois tubos foram de que não houve reação, ou seja, eles não possuíam o domínio da reação de óxido-redução como a transferência de elétrons e, portanto, suas conclusões foram equivocadas. Para escreverem o relatório era preciso transcrever as reações na forma de símbolos químicos, representando as substâncias por suas respectivas fórmulas e finalizando as reações com a formação dos produtos. Isso só foi realizado mesmo com o auxílio do professor, de acordo com as anotações da pesquisadora. Daí que, a análise da gesticulação dos estudantes leva à conclusão de que a técnica não foi empecilho para a aprendizagem do conceito, pois todos apresentaram manipulação apropriada à preparação da solução de ácido clorídrico e à coleta dos reagentes.

O problema de conceituação apresentado foi em relação às fórmulas das substâncias e ao conceito de reação de óxido-redução propriamente dito, já que os estudantes compreenderam o conceito de reação química. Assim, em relação aos conceitos de reação química, as gesticulações desses estudantes são classificadas de simbólicas, pois se encontram em terceiridade. Mas, em relação ao conceito de óxido-redução, suas gesticulações se mostraram indiciais, colocando-os em secundidade, visto que fazem relações pseudocausais dos experimentos com reações químicas, quando deveriam relacioná-las ao conteúdo de reações de oxirredução. Isso revela que ainda há um caminho a ser percorrido até a generalização, a interpretação do conteúdo visto em sala de aula aplicado ao experimento. Seria desejável avançar no que diz respeito às suas experiências colaterais, permitindo-os passar da secundidade à terceiridade.

\section{CONSIDERAÇÕES FINAIS}

Muitos autores da Educação Matemática (EDWARDS, 2009; KAPUT, 2009; MASCHIETTO; BUSSI, 2009; RADFORD, 2009; RADFORD; EDWARDS; ARZARELLO, 2009) investigaram os gestos e os multimodos na aprendizagem de conceitos matemáticos. Nesse sentido, nossa pesquisa teve um grande avanço ao estudarmos os gestos em conjunto com ações em atividades empíricas, que denominamos de gesticulações. Outros autores (LABURÚ, GOUVEIA; BARROS, 2009; ROTH; LAWLESS, 2002; MUCELIN; BELLINI, 2013; PADILHA; CARVALHO, 2008; PICCININI; MARTINS, 2004; PERALES PALLACIOS, 2006; WARTHA; REZENDE, 2011) apresentaram pesquisas a partir de uma perspectiva da semiótica peirciana. Em relação a estes, nosso trabalho se difere na utilização de 
uma reinterpretação da semiótica peirceana para análise das gesticulações. Alguns pesquisadores (GOLDIN-MEADOW; BEILOCK, 2010; KIM et al, 2011; ROTH; WELZEL, 2001; ROTH, 2001) principiaram a apresentação de dados dos gestos como ações, mas essa é a primeira pesquisa que relaciona a gesticulação (gestos e ações) no laboratório de química.

A reinterpretação da semiótica de Peirce oportunizou-nos a construção de um instrumento de análise para as gesticulações dos estudantes. Os resultados proporcionados pela observação das gesticulações na relação do experimento com o conteúdo (experiência colateral) nos permitiram a análise do processo de aprendizagem dos estudantes no laboratório de química. A presente pesquisa foi, na sua essência, um estudo sobre a gesticulação dos estudantes expressada nas relações que o estudante fez entre conteúdo e experimento. Observar a gesticulação foi muito importante e pode revelar muita coisa sobre o ensino e a aprendizagem porque "gesticular sobre um ato requer que você represente aquele ato" (GOLDIN-MEADOW e BEILOCK, 2010, p.672). A semiótica perciana nos ajudou a interpretar, entender, traduzir essas gesticulações, levando em conta não somente aspectos relacionados ao conteúdo da experimentação em si, mas aspectos subjacentes aos conteúdos necessários para que se tornassem possíveis as interações entre conteúdos passados e atuais.

Quando os estudantes estão aprendendo conceitos científicos, interagindo com várias formas de representação, tais como diagramas, gráficos, equações, experimentos, podem obter benefícios exclusivos. Em nossa pesquisa utilizamos a representação dos experimentos e no decorrer da atividade de ensino, por exemplo, os estudantes puderam deixar transparecer evidências que mostraram, muitas vezes, o não domínio de determinados conteúdos. Fizeram combinações inadequadas de reagentes, utilizaram materiais inadequados ou deixaram de utilizar materiais necessários à segurança, muito importantes para evitar danos à saúde de todos, fato este que, talvez, por outras representações, não fosse observado.

Dos dezesseis alunos analisados na tese, cinco se encontravam em primeiridade, dois em secundidade e nove em terceiridade de acordo com a figura abaixo.

Figura 8. Quadro de resultados dos 16 alunos analisados de acordo com o conhecimento científico relacionado à experimentação. 


\begin{tabular}{|l|c|c|c|c|}
\hline CATEGTICULAÇOESSIAS & ICONICAS & INDICIAIS & SIMBOLICAS & PORCENTAGEM \\
\hline PRIMEIRIDADE & 5 & & & $31 \%$ \\
\hline SECUNDIDADE & & 2 & & $12,5 \%$ \\
\hline TERCEIRICADE & & & 2 & $56,5 \%$ \\
\hline
\end{tabular}

Fonte: dados da pesquisa.

Esses dados representam que mais de $50 \%$ dos estudantes pesquisados realizaram interpretações, fizeram generalizações, arrolaram suas experiências colaterais ao desenvolvimento da experimentação, e suas gesticulações simbólicas nos permitiram dizer que a aprendizagem foi significativa. Como mostra a Figura 8, as gesticulações icônicas nos permitiram identificar mais de $31 \%$ de estudantes cujos conhecimentos prévios, ou seja, a experiência colateral, não colaboraram muito, pois não conseguiram relacionar essa experiência com o que realizavam no laboratório. Portanto, por não haver análise e por ser uma possibilidade, esses alunos foram categorizados na primeiridade. Encontram-se classificados, parcialmente, nesta categoria, aqueles que, por algum motivo, não conseguiram fazer relações de dualidade com partes de conteúdos necessários à atividade.

Figura 9. Quadro de resultados dos 16 alunos analisados de acordo com outros conteúdos abordados não relacionados diretamente ao experimento.

\begin{tabular}{|c|c|c|c|c|}
\hline GESTICULAÇOES & ICONICAS & INDICIAIS & SIMBOLICAS & PORCENTAGEM \\
\hline CATEGORIAS & & & & \\
\hline PRIMEIRIDADE & 1 & & & $6,25 \%$ \\
\hline TERCUNDIDADE & & 6 & & $37,5 \%$ \\
\hline
\end{tabular}

Fonte: dados da pesquisa.

Com o olhar voltado para o conteúdo da atividade, foi possível identificar $12,5 \%$ dos estudantes na categoria da secundidade (Figura 8), já que, pela sua definição, secundidade é a categoria que se relaciona com as ideias de ação e reação, conflito, dependência, dualidade. Agora, como mostra a figura 9, as gesticulações indiciais, se analisadas de acordo com os conteúdos abordados nos 
experimentos, mas oriundos das experiências colaterais dos estudantes, e não aqueles específicos da atividade, direcionaram nossas interpretações para a secundidade, na qual $37 \%$ dos alunos foram categorizados (Figura 9). Por conseguinte, no decorrer do estudo, constatamos que a compreensão a respeito do conteúdo ficou consolidada na maior parte dos alunos. Entre as dificuldades apresentadas, a maioria foi a respeito às técnicas e às normas de segurança de laboratório.

\section{CONSIDERAÇÕES FINAIS}

Este trabalho procurou mostrar a necessidade de se prestar atenção às ações exteriorizadas dos estudantes com a finalidade de conhecer se os significados dos conceitos por eles construídos foram adequados às atividades de ensino. Além da possibilidade de averiguar conceituações do aprendiz, a proposta se destaca por apontar para uma característica própria às atividades experimentais e que faz com que o modo de representação por gesticulação distinga-se como modo de representação privilegiado em relação a outros modos. Com o resultado desta pesquisa mostramos que a gesticulação é possível de ser analisada e interpretada. Dessa forma, o objetivo a que nos propusemos com a realização deste trabalho foi atingido.

Pouco consideradas e frequentemente menosprezadas no ensino, durante a materialização dos conceitos via atividades empíricas, manifestam-se questões de ordem técnica e operacional sem as quais tal materialização se torna impraticável. Essas questões referem-se aos procedimentos ou destrezas experimentais necessárias à manipulação envolvida na operacionalização de instrumentos e experiência em processos laboratoriais e técnicas. A gesticulação contribui não só como instrumento para o professor perscrutar o que os estudantes estão aprendendo do conhecimento científico em construção, como fizemos ver, mas, acima de tudo, quando vinculada à atuação empírica, torna-se parte fundamental da elaboração do pensamento desse conhecimento. No primeiro caso, o professor tem a possibilidade de redirecionar e corrigir ações didáticas, visando o melhor aprendizado do aluno. No segundo, permanece o princípio maior a respeito do modo representacional da gesticulação: a indissociável relação entre compreender e saber fazer. Em outras palavras, isso significa que o aprofundamento da compreensão conceitual científica abrange também saber aplicá-los em situações reais, ao mundo, o que, por sua vez, implica gestos em ação. 
Sabemos que professores já usam a gesticulação em seu processo de ensino, mas muitas vezes o fazem em uma situação de perigo, como no caso de observar um estudante manuseando ácidos sem luva. Dessa forma, este trabalho poderá contribuir para a formação de professores, que, observando comportamentos, encontrarão regularidades e isso fará com que treine o olhar para que, no momento de sala de aula, possa reconhecer essas gesticulações com mais facilidade ao observar os estudantes e compreender seus sinais corporais.

Esta pesquisa traz como contribuição o fato de poder ser aplicada a todas as ciências, na formação de professores ou com os estudantes do Ensino Fundamental e Médio. O professor das ciências tendo conhecimento dessas gesticulações e a filmagem da atividade, em uma oportunidade posterior, poderá mostrá-las aos estudantes e juntos identificarem as dificuldades, possibilitando uma melhora no ensino e aprendizagem da ciência em questão.

\section{REFERÊNCIAS}

CORRAZE, J. As comunicações Não-Verbais. Rio de Janeiro: Zahar, 1982.

EDWARDS, L. D. Gestures and conceptual integration in mathematical talk. Journal Educational Studies in Mathematics, v. 70, n. 2, p. 127-141, mar. 2009.

GIL, A. C. Didática do ensino superior. São Paulo: Atlas, 2006.

GOLDIN-MEADOW, S; BEILOCK, S. Action's influence on thought: the case of gesture. Perspectives on Psychological Science, v. 5, n. 6, p. 664-674, 2010.

GRILLO, M. Por que falar ainda em avaliação. Em: ENRICONE, D.; GRILLO, M. (Org.). Avaliação: uma discussão em aberto. 2a ed. Porto Alegre: EDIPUCRS, 2003.

HOFFMANN, J. Avaliação mediadora: uma prática em construção da pré-escola à universidade. Porto Alegre: Mediação, 2009.

IBRI, I. A. Ser e aparecer na filosofia de Peirce: o estatuto da fenomenologia. Cognitio Revista de Filosofia, São Paulo, n. 2, p. 67-75, 2001. (EDUC)

KASTENS, K. A; AGRAWAL, S; LIBEN, L.S. Research Methodologies in Science Education: The Role of Gestures in Geoscience Teaching and Learning. Journal of Geoscience Education: "Research Methodologies in Science Education" column, 2007. Disponível em: <http://web3.Ideo.columbia.edu/edu/eesj/directors/kastens/pubs/ Kastensetal_GeoGest_Long.pdf>. Acesso em: 19 mar. 2012.

KENDON, A. Gesture: visible action as utterance. United of America: Cambridge University Press, 2004.

KIM, M. et al. Children's gestures and the embodied knowledge of geometry. International Journal of Science and Mathematics Education, n. 9, p. 207-238, 2011.

LABURÚ, C. E; SILVA, O. H. M. da. O laboratório didático a partir da perspectiva da multimodalidade representacional. Ciência e Educação, v. 17, n. 3, Bauru, p. 721-734, 2011. 
LABURÚ, C. E.; GOUVEIA, A. A.; BARROS, M. A. Estudo de circuitos elétricos por meio de desenhos dos alunos: uma estratégia pedagógica para explicitar as dificuldades conceituais. Caderno Brasileiro de Ensino de Física, v. 26, n. 1, p. 24-47, 2009.

LUCKESI, C. C. Avaliação da aprendizagem escolar: estudos e proposições. 6ạ ed. São Paulo: Cortez, 1997.

. Prática educativa: processo versus produto. Revista ABC EDUCATIO, no 52, p.20-21, dez/2005-jan/2006. Disponível em: <http://www.luckesi.com.br/textos/abc_educatio/abceducatio_52_processo_educativo_pratica_ versus_produto.pdf>. Acesso em: 10 mar. 2015.

MASCHIETTO, M; BUSSI, M. G. B. Working with artefacts: gestures, drawings and speech in the construction of the mathematical meaning of the visual pyramid. Journal Educational Studies in Mathematics, v. 70, n. 2, p. 143-157, mar. 2009.

MIZUKAMI, M. da G. N. Ensino: as abordagens do processo. São Paulo: EPU, 1986.

NICOLAU, M. et. al. Comunicação e semiótica: visão geral e introdutória à semiótica de Peirce. Revista Eletrônica Temática, Ano VI, n. 8, ago. 2010.

NÖTH, W. Panorama da semiótica: de Platão a Peirce. São Paulo: Annablume, 1995.

PADILHA, J. N.; CARVALHO, A. M. P. Gestos e palavras utilizados pelos alunos do ensino fundamental em uma aula de conhecimento físico. 2008. Disponível em: <http://www.sbf1.sbfisica.org.br/eventos/epef/xi/sys/resumos/T03021.pdf>. Acesso em: 12 jul. 2009.

PEIRCE, C. S. The collected papers of Charles S. Peirce (CP). Electronic edition reproducing. 1994. Disponível em: <http://library.nlx.com/xtf/view?docld=peirce/peirce.00.xml;chunk.id=div. peirce. pmpreface.1;toc.id=; brand=default>. Acesso em: 8 dez. 2014.

Semiótica. São Paulo: Perspectiva, 1977.

PERALES PALLACIOS, F. J. Uso (y abuso) de la imagen en la enseñanza de las ciencias. Enseñanza de las Ciencias, v. 24, n. 1, p. 13-30, 2006.

PICCININI, C.; MARTINS, I. Comunicação multimodal na sala de aula de ciências: construindo sentidos com palavras e gestos. Ensaio. Pesquisa em Educação em Ciências, v. 6, n. 1, p. 26-40, 2004.

RADFORD, L. Why do gestures matter? Sensuous cognition and the palpability of mathematical meanings. Journal Educational Studies in Mathematics, v. 70, n. 2, p. 111-126, mar. 2009.

; BARDINI, C.; SABENA, C. Perceiving the general: the multisemiotic dimension of student's algebraic activity. Journal for Research in Mathematics Education, v. 38, n. 5, p. 507-530, 2007.

; EDWARDS, L.; ARZARELLO, F. Introduction: beyond words. Journal Educational Studies in Mathematics, v. 70, n. 2, p. 91-95, mar. 2009.

ROTH, W-M. Making use of gestures: the leading edge in literacy development. Communicating science: Examining the discourse. 2007. Disponível em: <http://education2.uvic.ca/Faculty/mroth/PREPRINTS/Literacy1.pdf>. Acesso em: 2 maio 2011.

; WELZEL, M. From activity to gestures and scientific languages. Journal of Research in Science Teaching, v. 38, n. 1, p. 103-136, 2001.

; LAWLESS, D. Scientific investigations, metaphorical gestures, and the emergence of abstract scientific concepts. Learning and Instruction, n. 12, p. 285-304, 2002. 
SANTAELLA, L. Matrizes da linguagem e pensamento: sonora, visual e verbal. 3a ed. 4a Reimp. São Paulo: Iluminuras, 2013.

A teoria geral dos signos: como as linguagens significam as coisas. São Paulo: Cengage Learning, 2012.

. O que é semiótica. São Paulo: Brasiliense, 2007.

Semiótica aplicada. São Paulo: Thomson, 2005.

; NÖTH, W. Imagem: cognição, semiótica, mídia. São Paulo: Iluminuras, 1998.

VASCONCELLOS, C. dos S. Avaliação: concepção dialética-libertadora do processo de avaliação escolar. São Paulo: Libertad, 1995.

WARTHA, E. J.; REZENDE, D. B. Os níveis de representação no ensino de química e as categorias da semiótica de Peirce. Investigações em Ensino de Ciências, v. 16, n. 2, p. 275-290, 2011. 